\title{
Hubungan Kualitas Tidur dengan Konsentrasi Belajar Siswa Kelas VII dan VIII
}

\section{Relationship Quality Sleep with Learning Concentration Class VII and VIII Students}

\author{
Ida Gustiawati ${ }^{1}$, Arita Murwani ${ }^{2}$ \\ 1. STIKes Surya Global Yogyakarta, Indonesia \\ 2. STIKes Surya Global Yogyakarta, Indonesia \\ *Email Korespondensi : gustiawatiida@gmail.com
}

\begin{abstract}
Abstrak
Latar belakang: Tidur merupakan kebutuhan dasar manusia. Kualitas tidur buruk berdampak terhadap kemampuan dalam beraktifitas, diantaranya mempengaruhi penurunan konsentrasi. Penurunan konsentrasi belajar merupakan masalah bagi kalangan pelajar, yang menunjukkan keadaan mengantuk saat belajar, kurang antusias atau kurang perhatian. Hal ini dilihat dari kulitas tidur buruk yang dialami siswa kelas VII dan VIII MTs Binaul Ummah Bawuran Pleret Bantul Yogyakarta.

Tujuan: Mengetahui hubungan kualitas tidur dengan konsentrasi belajar siswa kelas VII dan VIII di MTs Binaul Ummah Bawuran Pleret Bantul Yogyakarta.

Metode: Penelitian ini adalah penelitian kuantitatif dengan desain cross sectional. Populasi penelitian siswa kelas VII dan VIII MTs Binaul Ummah Bawuran Pleret Bantul Yogyakarta sebanyak 110 siswa. Sampel diambil secara random sampling terhadap 65 siswa. Pengumpulan data menggunakan kuesioner. Analisis data menggunakan uji mann-whitney.

Hasil: Kualitas tidur siswa mayoritas buruk $44(67,6 \%)$ dan konsentrasi belajar siswa mayoritas kurang $36(55,3 \%)$. Hasil uji kolerasi mann-whitney diperoleh hasil nilai sig 0,006 < 0,05.

Kesimpulan: Terdapat hubungan antara kualitas tidur dengan konsentrasi belajar siswa kelas VII dan VIII di MTs Binaul Ummah Bawuran Pleret Bantul Yogyakarta. Hal ini karena kualitas tidur buruk mempengaruhi konsentrasi seseorang saat proses belajar.
\end{abstract}

Kata kunci: Konsentrasi Belajar; Kualitas Tidur; PSQI

\begin{abstract}
Background: Sleep is a basic human need. Poor sleep quality has an impact on the ability to do activities, including poor concentration. Poor learning concentration is a problem for many students, who show a state of drowsiness while studying, less enthusiastic, or less attentive in class. This could be seen from the poor sleep quality experienced by students in grade VII and VIII at MTs Binaul Ummah Bawuran Pleret Bantul, Yogyakarta.

Objective: To determine the relationship between sleep quality and the learning concentration of grade VII and VIII students at MTs Binaul Ummah Bawuran Pleret Bantul, Yogyakarta.

Methods: This study was a quantitative study with a cross-sectional design. The population of the research was 110 students of class VII and VIII MTs Binaul Ummah Bawuran Pleret Bantul Yogyakarta. The sampling technique used in the study was random sampling involving 65 students. Data collection was done with a questionnaire and the Mann-Whitney method was used to analyze the data.

Results: The sleep quality of the majority of the student was poor, which consist of 44 students (67.6\%) and poor learning concentration was seen in 36 students (55.3\%). The
\end{abstract}


results of the Mann-Whitney correlation test showed a significant correlation between poor sleep quality and concentration, with a p-value of 0.006 .

Conclusion: There was a relationship between sleep quality and the learning concentration in students grade VII and VIII at MTs Binaul Ummah Bawuran Pleret Bantul Yogyakarta. This implied that poor sleep quality might affect concentration during the studying or learning process.

Keywords: Learning Concentration; Sleep Quality; PSQI

\section{PENDAHULUAN}

Tidur merupakan kebutuhan setiap orang, yang dibutuhkan oleh tubuh. Tidur sendiri memiliki peranan penting bagi otak. Pada saat seseorang tidur, selama tidur tersebut otak bekerja untuk memulihkan kembali sistem kerja otak, tidur juga dapat dapat memulihkan kembali memorimemori dan memperkuat informasi yang telah dipelajari atau yang telah ada sehingga otak dapat berfungsi kembali secara efektif. Pada remaja usia 12-18 tahun membutuhkan waktu untuk tidur selama 8-9 jam setiap hari dan untuk dewasa membutuhkan waktu untuk tidur selama 7-8 jam setiap hari.(1)

Sebuah lembaga American Academy of Pediatris menyatakan di Amerika bahwa remaja usia sekolah sangat membutuhkan kualitas tidur dan tidur yang cukup. Kualitas tidur dan tidur yang cukup dapat mengurangi berbagai masalah negatif seperti masalah kesehatan, mengalami kecelakaan, masalah menurunnya konsentrasi dan memori serta kesehatan mental seseorang.(2)

Terdapat lebih dari 90\% remaja di Indonesia rata-rata waktu tidurnya kurang dari 8-10 jam setiap malamnya. Penelitian sebelumnya dijelaskan bahwa usia remaja terdapat $10 \%$ yang memiliki waktu tidur kurang dari 6 jam per malamnya.(3) Penelitian tersebut juga menjelaskan remaja sekolah harusnya memerlukan waktu tidur 8-10 jam per hari untuk mengistirahatkan tubuhnya yang setelah seharian belajar. Lamanya waktu tidur yang dimiliki usia remaja 8-10 jam per hari sudah termasuk waktu tidur dan istirahat yang dimanfaatkan pada siang hari.

Tidur yang buruk akan berdampak pada kemampuan kita dalam beraktifitas sehari-hari. Selain itu tidur juga dapat mempengaruhi konsentrasi seseorang, kualitas tidur yang buruk dapat menyebabkan menurunkan daya ingat atau konsentrasi seseorang baik dalam hal belajar atau mengingat sesuatu, sehingga untuk mendapatkan konsentrasi yang baik harus memperhatikan pola tidur dan kualitas tidur supaya dapat berkonsentrasi dengan baik.(4)

Berdasarkan hasil studi pendahuluan yang dilakukan di MTs Binaul Ummah Bawuran Pleret Bantul pada 12 Oktober 2019, didapatkan data jumlah siswa kelas VII sebanyak 34 siswa dan kelas VIII sebanyak 31 siswa. Berdasarkan wawancara yang dilakukan peneliti pada 3 siswa dan 2 guru di sekolah tersebut, siswa menyatakan kurang berkonsentrasi pada saat belajar, siswa sering tidur dikelas pada saat belajar, karena siswa tersebut tidurnya kurang dari 8 jam. Rata-rata siswa tersebut tidurnya kurang lebih 5-6 jam setiap malamnya, alasannya karena ada kegiatan malam yang sudah terjadwal dari jam 20.00-22.00 dari mulai hari seninminggu. Kegiatannya sudah terjadwal tersebut bersifat wajib diikuti oleh siswa setiap malamnya, karena jika tidak mengikuti kegiatan tersebut akan mendapatkan hukuman dari ustadzah di pesantren tersebut.

Akibat dari kurangnya jam tidur siswa tersebut, pada saat proses pembelajaran di kelas sering mengantuk sehingga konsentrasinya berkurang, selain itu siswa kurang mengerti apa yang sudah dijelaskan, siswa masih bingung ketika ditanya oleh guru tentang materi apa yang dijelaskan, siswa masih banyak bertanya ketika disuruh mengerjakan soal, sehingga guru yang 
mengajar harus menjelaskan kembali materi apa yang sudah diberikan. Berdasarkan hal tersebut, maka dirasa perlu untuk meneliti tentang hubungan kualitas tidur dengan konsentrasi belajar siswa kelas VII dan kelas VIII di MTs Binaul Ummah Bawuran Pleret Bantul Yogyakarta.

\section{METODE}

Penelitian ini merupakan penelitian kuantitatif dengan pendekatan cross sectional. Teknik pengambilan sampel menggunakan simple random sampling dengan jumlah sampel sebanyak 65 siswa. Kriteria inklusi dalam penelitian ini adalah siswa kelas VII dan kelas VIII MTs Binaul Ummah Bawuran Pleret Bantul Yogyakarta dan siswa yang bersedia menjadi responden yang dinyatakan tertulis melalui surat persetujuan menjadi responden.

Data yang diperoleh akan dianalisis menggunakan analisis univariat dan analisis bivariat menggunakan program SPSS Software Versi 16.0. untuk melihat hubungan kualitas tidur dengan konsentrasi belajar. Instrumen penelitian menggunakan kuesioner The Pittsburg Sleep Quality Index (PSQI) untuk mengukur kualitas tidur. Kuesioner kualitas tidur Pittsburgh Sleep Quality Index (PSQI) diperkenalkan pertama kali pada tahun 1989 Daniel J. Buysse di Universitas Pittsburgh. Kuesioner kualitas tidur sudah baku sehingga peneliti tidak melakukan uji validitas pada kuesioner tersebut. Kuesioner kualitas tidur Pittsburgh Sleep Quality Index (PSQI) telah di translate dan diterjemahkan ke dalam Bahasa Indonesia menggunakan jogjatranslate.com oleh Iqbal.(4) Pengukuran pada kuesioner kualitas tidur menggunakan skala kategorik ordinal untuk variabelnya. Kuesioner kualitas tidur memiliki 7 komponen penilaian disetiap item pertanyaannya yaitu kualitas tidur secara subyektif, waktu yang diperlukan untuk memulai tidur, lamanya waktu tidur, efisiensi tidur, gangguan tidur yang sering dialami pada malam hari, penggunaan obat untuk membantu tidur, dan gangguan tidur yang sering dialami pada siang hari. Jawaban dari 7 komponen tersebut memiliki jawaban dan skor masing-masing yaitu memiliki skor 0-3 = 0 (Tidak pernah dalam sebulan terakhir), $1=1$ (Satu kali seminggu), 2=2 (Dua kali seminggu) dan 3=>3 (lebih dari 3 kali seminggu). Skor akhir dari kualitas tidur adalah skor $\leq 5=$ kualitas tidur baik dan skor $>5=$ kualitas tidur buruk.

Pengukuran konsentrasi belajar menggunakan kuesioner konsentrasi belajar yang diadopsi dari Waliyanti (2016)(5) dan dilakukan uji validitas ulang oleh peneliti dengan menggunakan rumus alpha cronbach dan memperoleh nilai alpha cronbach 0,809. Nilai tersebut sudah lebih dari konstanta yaitu 0,7807. Menurut Riwidikdo (2012)(6) kuesioner dikatakan reliabel bila memiliki nilai $\alpha=0,7807$ sehingga kuesioner tersebut sudah reliabel dan dapat digunakan untuk penelitian. Kuesioner konsentrasi belajar meliputi 4 komponen diantaranya yaitu memusatkan perhatian saat proses belajar, mengemukakan ide atau pendapat dan aktif saat proses pembelajaran, mengemukakan ide atau pendapat dan aktif saat proses pembelajaran dan tenang dalam belajar. Cara pengukuran skor menggunakan skala likert, hasil pengkategorian menggunakan skala ordinal sehingga didapatkan konsentrasi belajar sebagai berikut: baik: 76-100\%, cukup: 56-75\%, kurang: <56\%.

Analisis data penelitian menggunakan univariat dan bivariat. Analisis univariat digunakan untuk menggambarkan karakteristik responden. Analisis bivariate menggunakan uji mann-whitney dengan $\alpha=<0.05$. Peneliti menggunakan bantuan software computer SPSS 16.0 untuk proses pengolahan data dan analisis statistik. 
HASIL

Tabel 1. Karakteristik Responden berdasarkan, Jenis Kelamin, Usia, dan Kelas

\begin{tabular}{clcc}
\hline No & \multicolumn{1}{c}{ Karakteristik Responden } & Jumlah (n) & Persentase (\%) \\
\hline 1 & Jenis kelamin & 27 & \\
& a. Laki-laki & 38 & 41,5 \\
2 & b. Perempuan & & 58,5 \\
& Usia & 1 & \\
& a. 11 tahun & 8 & 1,5 \\
& b. 12 tahun & 28 & 12,3 \\
& c. 13 tahun & 25 & 43,1 \\
& d. 14 tahun & 3 & 38,5 \\
& e. 15 tahun & & 4,6 \\
Kelas & 34 & 52,3 \\
& a. Kelas VII & 31 & 47,7 \\
\hline & b. Kelas VIII & 65 & 100 \\
\hline
\end{tabular}

Tabel 1 didapatkan data bahwa sebagian besar siswa di MTs Binaul Ummah Bawuran Pleret Bantul Yogyakarta berjenis kelamin perempuan dengan jumlah 38 orang $(58,4 \%)$, dan laki-laki berjumlah 27 (41,5\%). Dapat diketahui bahwa rata-rata usia responden usia 13 tahun sebanyak 28 orang $(43,0 \%)$, dan usia 14 tahun sebanyak 25 orang $(38,4 \%)$.

Tabel 2. Kualitas Tidur Siswa Kelas VII dan VIII di MTs Binaul Ummah Bawuran Pleret Bantul Yogyakarta

\begin{tabular}{cccc}
\hline No & Kategori & Jumlah $(\mathrm{n})$ & Persentase $(\%)$ \\
\hline 1 & Buruk & 44 & 67,6 \\
2 & Baik & 21 & 32,3 \\
\hline & Total & 65 & 100 \\
\hline
\end{tabular}

Tabel 2 menunjukan bahwa sebagian besar siswa siswi di MTs Binaul Ummah Bawuran Pleret Bantul Yogyakarta mengalami kualitas tidur buruk sebanyak 44 orang $(67,6 \%)$ dan untuk kualitas tidur baik sebanyak 21 orang $(32,3 \%)$. Hasil penelitian sebagian besar siswa siswi tersebut mengalami kualitas tidur buruk, hal tersebut dikarenakan jadwal yang padat sehingga siswa siswi tersebut harus mengikuti jadwal kegiatan sekolah dan pesantren yang sudah terjadwal mulai dari jam 03.30 pagi sampai jam 22.00 malam.

Tabel 3 menunjukan bahwa sebagian besar siswa siswi di MTs Binaul Ummah Bawuran Pleret Bantul Yogyakarta konsentrasi belajar kurang sebanyak 36 orang (55,3\%), konsentrasi belajar cukup sebanyak 22 orang $(33,8 \%)$, dan konsentrasi baik sebanyak 7 orang $(10,75)$.

Tabel 3. Konsentrasi Belajar Siswa Kelas VII dan VIII di MTs Binaul Ummah Bawuran Pleret Bantul Yogyakarta

\begin{tabular}{cccc}
\hline No & Kategori & Jumlah $(\mathrm{n})$ & Persentase (\%) \\
\hline 1 & Kurang & 36 & 55,3 \\
2 & Cukup & 22 & 33,8 \\
3 & Baik & 7 & 10,7 \\
\hline & Total & 65 & 100 \\
\hline
\end{tabular}

Hasil penelitian menunjukkan bahwa sebagian besar siswa-siswi mengalami konsentrasi belajar kurang, hal ini memberikan indikasi adanya hubungan antara kualitas kualitas tidur seseorang terhadap konsentrasi belajar pada siswa siswi tersebut. 
Tabel 4. Hubungan Kualitas Tidur dengan Konsentrasi Belajar Siswa Kelas VII dan VIII di MTs Binaul Ummah Bawuran Pleret Bantul Yogyakarta

\begin{tabular}{|c|c|c|c|c|c|c|c|c|}
\hline \multirow{3}{*}{ No } & \multirow{3}{*}{$\begin{array}{c}\text { Kualitas } \\
\text { Tidur }\end{array}$} & \multicolumn{6}{|c|}{ Konsentrasi Belajar } & \multirow{3}{*}{$p$ Value } \\
\hline & & \multicolumn{2}{|c|}{ Kurang } & \multicolumn{2}{|c|}{ Cukup } & \multicolumn{2}{|c|}{ Baik } & \\
\hline & & $\mathrm{n}$ & $\%$ & $\mathrm{n}$ & $\%$ & $\mathrm{n}$ & $\%$ & \\
\hline 1 & Buruk & 29 & 80,5 & 10 & 28,6 & 5 & 71,4 & 0,006 \\
\hline 2 & Baik & 7 & 19,4 & 12 & 46,4 & 2 & 42,9 & \\
\hline & Total & 36 & 100 & 22 & 100 & 7 & 100 & \\
\hline
\end{tabular}

Berdasarkan hasil uji mann-whitney nilai $p$ value adalah $0,006<0,05$ artinya ada hubungan yang signifikan antara hubungan kualitas tidur dengan konsentrasi belajar siswa kelas VII dan VIII di MTs Binaul Ummah Bawuran Pleret Bantul Yogyakarta.

\section{PEMBAHASAN}

\section{Karakteristik Responden}

Penelitian menunjukan bahwa mayoritas siswa yang menjadi responden berjenis kelamin perempuan 38 orang $(58,4 \%)$, dan siswa laki-laki berjumlah $27(41,5 \%)$. Distribusi usia responden adalah 13 tahun sebanyak 28 orang (43,0\%), dan usia 14 tahun sebanyak 25 orang $(38,4 \%)$. Jumlah siswa siswi sebagian besar kelas VII dengan jumlah 34 siswa $(52,3 \%)$, dan kelas VIII dengan jumlah 31 siswa $(47,6 \%)$.

\section{Kualitas Tidur Siswa Kelas VII dan VIII di MTs Binaul Ummah Bawuran Pleret Bantul Yogyakarta}

Hasil penelitian menunjukkan bahwa sebagian besar responden memiliki kualitas tidur buruk. Hal ini disebabkan jadwal kegiatan sekolah dan pesantren sangat padat dari pagi sampai malam, sehingga istirahat yang dibutuhkan siswa siswi tersebut kurang. Kegiatan yang berlangsung mulai dari jam 03.30 pagi sampai jam 22.00 sudah terjadwal dengan baik sehingga siswa siswi tersebut bersifat wajib mengikuti setiap kegiatan yang sudah terjadwal dengan baik.

Hasil penelitian ini didukung dengan penelitian sebelumnya bahwa di pondok pesantren seluruh kegiatan sudah terjadwal dan disesuiakan dengan baik. (3) Dimulai dari waktu tidur dan istirahat yang dimulai pada jam 22.00 sampai jam 04.00 pagi. Dimana untuk kegiatan pagi tersebeut para santri maupun santriwati melakukan aktivitas rutin yang sudah terjadwal dari mulai solat subuh berjamaah dimasjid dan setelah itu para santri maupun santriwati melanjutkan aktivitas sesuai jadwal masing-masing. Sehingga, santri di pondok pesantren memiliki waktu tidur kurang dari 8 jam setiap harinya. Akibat dari kurangnya jam tidur siswa tersebut, pada saat proses pembelajaran dikelas sering mengantuk sehingga konsentrasinya berkurang.

\section{Konsentrasi Belajar Siswa Kelas VII dan VIII di MTs Binaul Ummah Bawuran Pleret Bantul Yogyakarta}

Hasil penelitian ini sesuai dengan kualitas tidur yang masuk dengan kategori buruk, maka hasil dari konsentrasi belajar juga termasuk ke dalam kategori kurang. Berdasarkan hasil penelitian yang didapatkan bahwa sebanyak 55,3\% konsentrasi belajar dalam kategori kurang, dikarenakan waktu istirahat yang kurang sehingga dapat mempengaruhi konsentrasi belajar pada siswa-siswi MTs Binaul Ummah. Berdasarkan hasil wawancara yang dilakukan peneliti siswa menyatakan kurang berkonsentrasi pada saat belajar, siswa sering tidur dikelas pada saat belajar, karena siswa tersebut tidur kurang dari 8 jam. Rata-rata siswa tersebut tidurnya kurang lebih 5-6 jam setiap malamnya. Maka kualitas tidur yang buruk dapat mempengaruhi 
konsentrasi belajar siswa-siswi tersebut, begitupun sebaliknya jika kualitas tidur seseorang baik maka konsentrasinya belajarnya juga baik.

Hal ini didukung dengan penelitian yang dilakukan sebelumnya bahwa tingkat konsentrasi kedua faktor yaitu faktor internal dan faktor eksternal.(7) Faktor internal yaitu faktor jasmaniah seperti cukup tidur dan istirahat. Kualitas tidur yang buruk dapat mempengaruhi tingkat konsentrasi, sehingga untuk meningkatkan konsentrasi yang baik, diperlukan juga kualitas tidur yang baik.

Hasil penelitian ini juga didukung dengan penelitian sebelumnya bahwa kondisi kurang tidur dapat berdampak seperti kurangnya konsentrasi belajar dan gangguan kesehatan. Pada orang yang mengalami gangguan tidur dimalam hari akan merasa lelah dan merasa mengantuk disiang hari sehingga tidak dapat berkonsentrasi dalam aktivitas dan belajar sehingga dapat mempengaruhi nilai anak didik menurun.(8)

\section{Hubungan Kualitas Tidur dengan Konsentrasi Belajar Siswa Kelas VII dan VIII di MTs Binaul Ummah Bawuran Pleret Bantul Yogyakarta}

Hasil penelitian ini menunjukkan bahwa ada hubungan yang signifikan antara kualitas tidur dengan konsentrasi belajar siswa kelas VII dan VIII di MTs Binaul Ummah Bawuran Pleret Bantul Yogyakarta, dengan hasil analisis korelasi menggunakan Mann-Whitney didapatkan $p$ value $=0,006(\mathrm{p}<0,05)$ artinya $\mathrm{H}_{\mathrm{a}}$ diterima dan $\mathrm{H}_{\mathrm{o}}$ ditolak.

Terlihat pada Tabel 4 bahwa kualitas tidur dengan konsentrasi belajar menunjukan bahwa sebagian besar siswa siswi di MTs Binaul Ummah Bawuran Pleret Bantul Yogyakarta memiliki kualitas tidur buruk dengan konsentrasi belajar kurang sebanyak (80,5\%), kualitas tidur baik dengan konsentrasi cukup sebanyak (46,4\%), dan konsentrasi belajar baik jika kualitas tidur buruk dengan persentase $(71,4 \%)$, sedangkan jika kualitas tidur baik dengan persentase $(42,9 \%)$. Hal ini dikarenakan kurangnya istirahat (tidur) sehingga menyebabkan siswa siswi tersebut kurang berkonsentrasi pada saat belajar dikelas. Apabila tingkat konsentrasi itu kurang maka menjadi tidak maksimal konsentrasi seseorang. Salah satu hal yang mengindikasikan ini ditunjukan dengan kurangnya istirahat (tidur) yang dibutuhkan untuk memulihkan kembali fungsi-fungsi organ tubuh yang seharian sudah bekerja agar tubuh dapat bugar kembali untuk bekerja.

Usia remaja 12-18 tahun membutuhkan waktu tidur sekitar 8-10 jam. Kebutuhan tidur pada setiap orang memiliki kebutuhan tidur dan pola tidur yang berbeda- beda. Pada remaja kebutuhan tidurnya sangat berbeda dibandingkan dengan usia lainnya, hal ini disebabkan diakhir masa pubertas. Pada masa pubertas dimana remaja mengalami sejumlah perubahan yang seringkali mengurangi waktu tidur. Tidur memiliki peran penting untuk tubuh dimana dapat dilihat dari keadaan psikologis seseorang dalam berfikir dan mental seseorang. Selain itu juga akibat dari kurangnya tidur dapat menurunkan tingkat konsentrasi seseorang dan tingkat emosionalnya tidak dapat terkontrol dengan baik sehingga mudah marah dan susah untuk mengambil serta membuat keputusan. (9)

Tidur juga dapat memengaruhi produktivitas dan aktivitas. Menurunnya kemampuan seseorang untuk berpikir dan sulit untuk berkonsentrasi bisa disebabkan oleh kurangnya tidur. Pada saat tidur otak bekerja untuk membersihkan toksin yang dihasilkan otak untuk berfikir selama seharian bekerja, sehingga tidur yang cukup dan kualitas tidur yang baik dapat menyegarkan kembali sistem kerja otak. (2)

\section{SIMPULAN}

Kualitas tidur mempengaruhi konsentrasi belajar siswa kelas VII dan VIII di MTs Binaul Ummah Bawuran Pleret Bantul Yogyakarta. Hal ini dapat dilihat dari kualitas tidur siswa 
yang buruk sehingga dapat mempengaruhi konsentrasi belajar siswa dalam proses menerima pelajaran disekolah.

\section{SARAN}

Penelitian ini diharapkan dapat menjadi bahan bacaan atau referensi untuk peneliti selanjutnya mengenai faktor-faktor lain yang mempengaruhi kualitas tidur dan konsentrasi belajar sehingga hasilnya dapat dilihat dari sudut pandang yang berbeda. Selain itu, disarankan untuk penelitian selanjutnya dapat menggunakan sampel yang lebih luas lagi agar hasil lebih baik.

\section{UCAPAN TERIMA KASIH}

Peneliti menyampaikan terima kasih kepada kepala sekolah MTs Binaul Ummah Bawuran Pleret Bantul Yogyakart dan responden penelitian siswa kelas VII dan VIII dan MTs Binaul Ummah Bawuran Pleret Bantul Yogyakarta yang telah memberikan ijin penelitian dan bersedia menjadi responden penelitian.

\section{DAFTAR PUSTAKA}

1. Rahmadi FM. Hubungan Kualitas Tidur terhadap Konsentrasi Mahasiswa Fakultas Kedokteran Universitas Muhammadiayah Palembang Sebelum Mengikuti Ujian. 2017;

2. Huda N. 100 Fakta Seputar Tidur yang Perlu Anda Tahu. Jakarta: PT Elex Media Komputindo; 2016.

3. Mustikawati F, Prabamurti P, Indraswari R. Faktor- Faktor Yang Berhubungan Dengan Perilaku Pola Tidur Santriwan Dan Santriwati Kelas Xi Ma Pondok Pesantren Modern Islam Assalaam Surakarta. J Kesehat Masy. 2016;4(5):299-308.

4. Iqbal M. Hubungan Aktivitas Fisik Dengan Kualitas Tidur Mahasiswa Perantau Di Yogyakarta. J Chem Inf Model. 2017;53(9):1689-99.

5. Waliyanti E. Analisis faktor-faktor yang mempengaruhi Konsentrasi Belajar Mahasiswa Program Studi Ilmu Keperawatan Universitas Muhammadiyah Yogyakarta. 2016;

6. Handoko R. Statistik Kesehatan. Yogyakarta: Mitra Cendikia Press; 2012.

7. Andriani. Hubungan Kualitas Tidur Terhadap Konsentrasi Belajar Mahasiswa Akademi Kebidanan Internasional Pekanbaru Tahun 2016. Sci J Maret [Internet]. 2016;4(01):38390. Tersedia pada: http://ojs.stikesprima-jambi.ac.id/index.php/sc/article/viewFile/85/83

8. Awal HQ. Hubungan Antara Kualitas Tidur Dengan Prestasi Belajar Pada Mahasiswa Keperawatan Angakatan 2014 UIN Alaludin Makasar. 2017;

9. Kozier B. Buku Ajar Pundamental Keperawatan: Konsep, Proses, dan Praktik. Jakarta: EGC; 2011. 